\title{
溶接止端部にき裂を有する構造用圧延鋼のピーニングによる疲労限度向上 およびき裂の無害化*
}

\author{
北條 恵司 ${ }^{* 1}$, 高橋 宏治 ${ }^{* 2}$, 安藤 柱 $^{* 2}$, 関口 祐司 ${ }^{* 3}$ \\ Improvement of Fatigue Limit and Rendering Crack Harmless by Peening for Rolled Steel \\ Containing a Crack at the Weld Toe Zone
}

\author{
Keiji HOUJOU*1, Koji TAKAHASHI, Kotoji ANDO and Yuji SEKIGUCHI \\ ${ }^{* 1}$ Oyama National College of Technology, Dept. of Mechanical Engineering, \\ 771 Nakakuki Oyama Tochigi, 323-0806 Japan
}

\begin{abstract}
This study describes an investigation of the effect of peening on the fatigue limit of rolled steel containing a crack at the weld toe. 3-point bending specimens with a weld zone were prepared for fatigue test. An artificial semi-circular slit was made into the weld toe, and subsequently the weld toe was peened by needle-peening. Using those specimens, bending fatigue tests were carried out. The following results were obtained. (1) The fatigue limits of specimens containing a slit improved considerably by peening. (2) The fracture occurred from outside the slit. Moreover, the specimens recovered to fatigue limits up to that of non-slit specimens. (3) A slit of 0.4- $1.2 \mathrm{~mm}$ in depth was rendered harmless by the peening.
\end{abstract}

Key Words: Fatigue, Peening, Crack, Weld Zone, Rendering Crack Harmless

\section{1. 緒言}

船舶，橋梁，圧力容器などの大型構造物は多くの部分で溶接継ぎ手が採用されている．しかし溶接時の熱影響 のため溶接止端部には大きな引張り応力が残留し，しばしばそこから疲労き裂が発生し破壊に至る事故事例が問 題となっている. さらに近年では, 第一種圧力容器が使用開始後 40 年を超えるものが多く使用されており, そ の安全性保障が盛んに議論されている. これらの大型構造物では危険な疲労き裂が発生した場合, 構造部分全体 を交換せざるを得ないため莫大な保全費用が予測される. しかし発生した疲労き裂であったとしても疲労強度を 低下させない無害なき裂に変化させられれば，構造物の信頼性向上のみならず保全費用の大幅な削減が可能にな るだろう。

近年，ショットピーニングなどにより導入される圧縮残留応力の効果で，これら構造物の疲労き裂や応力腐食 割れを防止する研究が見受けられるようになった 1)-2). しかし，才でに発生した疲労き裂を圧縮残留応力により 無害化し, 使用し続けられるようにする研究は例を見ない. 著者らは, 既往の研究でショットピーニングや過大 荷重効果などを使用したき裂の無害化に関する研究を進めてきた ${ }^{3)-6)}$. その結果, 高強度鋼に対しては深さ $0.2 \mathrm{~mm}$ 程度の人工き裂を十分に無害化できることを確認している.

そこで, 本研究では溶接構造用圧延鋼材 SM490A の溶接止端部に人工き裂を導入し, そこにエアー式ニードル ピーニングおよび超音波式ピーニングを施工することによる疲労強度の改善に関する調查を行った．これらのピ ーニング装置の特徵は可搬性があり, 屋外で作業できることである. よって大型構造物に発生したき裂を現場で 無害化することを模擬することができる. それにより溶接部に発生したき裂を, どの程度の寸法まで無害化でき るのかを知ることは工業的に極めて興味深い. 本研究ではこれらについて詳細に調查したので報告する.

\footnotetext{
* 原稿受付 2012 年 10 月 18 日

*1 正員, 国立小山工業高等専門学校 機械工学科（干323-0806 杤木県小山市中久喜 771）

*2 正員, 横浜国立大学院

*3 国立小山工業高等専門学校 専攻科

E-mail: houjou@oyama-ct.ac.jp
} 


\section{$2 \cdot 1$ 供試材}

\section{2. 供試材および実験方法}

供試材として溶接構造用圧延鋼材 SM490A を用いた．その化学成分および引張り試験結果を表 1 に示す．表 1 より，炭素量は $0.15 \%$ で $0.2 \%$ 而力は $371 \mathrm{MPa}$ である. 図 1 に試験片形状を示す. 図 1 (a)に示すように, 試験片中 央に溶接部が位置するように，試験片よりも相当大きな素材板をアーク溶接により作製し，そこから必要な形状 を切り出した. そのとき素材の圧延方向が試験片長手方向に一致するように $60^{\circ} \mathrm{X}$ 開先の板 2 枚を突き合わせ溶 接した。十分な残留応力が発生するように，溶接時は素材板を固定せず，入熱は $30 \mathrm{kj} / \mathrm{cm}$ 程度，パス間の許容温 度は 200 度で片面溶接後十分に冷却を行った後に反対面の溶接を行った。

試験片形状を図 1 (b)に示寸．試験片は 3 点曲げ疲労試験用で支点間距離 $100 \mathrm{~mm} ，$ 厚み $20 \mathrm{~mm}$ である．図(a)の 素材から, 最大引張り応力が発生する位置と溶接止端部が一致するよう試験片を切り出した．また深さ $12 \mathrm{~mm} の$ $\mathrm{V}$ 溝側を溶接したときに発生した予盛りは, 荷重を負荷するため除去加工した. 次に止端部から外側 $0.5 \mathrm{~mm}$ 以内 の位置 A 部に機械加工で人工き裂（以降，スリットと呼ぶ）を導入した．スリット面は応力と垂直方向に半円型 に加工した．その深さ $a$ は $0.4,0.8$ および $1.2 \mathrm{~mm} の 3$ 種類である.

スリットを導入した後に，東洋精鋼（株）でピーニング処理を行った．図1(c) に示すようにスリット部を含め た溶接止端部(1)には東洋精鋼製エアー式ニードルピーニング（PPP）を，また止端部外側 $20 \mathrm{~mm}$ の範囲(2)に熱影 響部（HAZ）の応力改善を目的として同社製超音波式ボアードガンタイプピーニング（UNP）をそれぞれ施工し た. それぞれのピーニング条件を表 2 に示寸. (1)PPP は先端半径 $1.5 \mathrm{~mm}$ の 1 本の鋼製ピンにエアー圧力を直接伝 達するため, 大きな塑性変形（くぼみ）を伴う。一方(2)UNP は 18 本のピンに $20 \mathrm{kHz}$ の超音波振動を伝達し平面 的な加工が可能である。いずれも伝達エネルギーが大きいためアークハイトの測定範囲を超えたため測定はでき なかった．本研究では図 1(c)に示寸ように，止端部1)にはPPP を，止端部から外側 $20 \mathrm{~mm}$ の範囲(2)には UNP を 組み合わせて加工を行った. 以降, これをピーニングと呼ぶ.

\section{$2 \cdot 2$ 実験方法}

2.1 節で得られた試験片を用いて, 室温大気中にて繰り返し 3 点曲げ疲労試験を行った. 試験機は島津製サーボ パルサー50kN であり, 荷重条件は応力比 $R=0.05$, 繰り 返し周波数 $f=20 \mathrm{~Hz}$ の正弦応力波形, 荷重一定制御であ る. 疲労試験は繰り返し数 $N_{f}=5 \times 10^{6}$ 回で打ち切り, 応力振幅 $\sigma_{\mathrm{a}}$ の応力階差が $5 \%$ 以内の間に破断と破断しなか った試験が現われた場合，破断しなかった応力振幅 $\sigma_{\mathrm{a}}$ を疲労限度 $\sigma_{\mathrm{w}}$ と定義した.

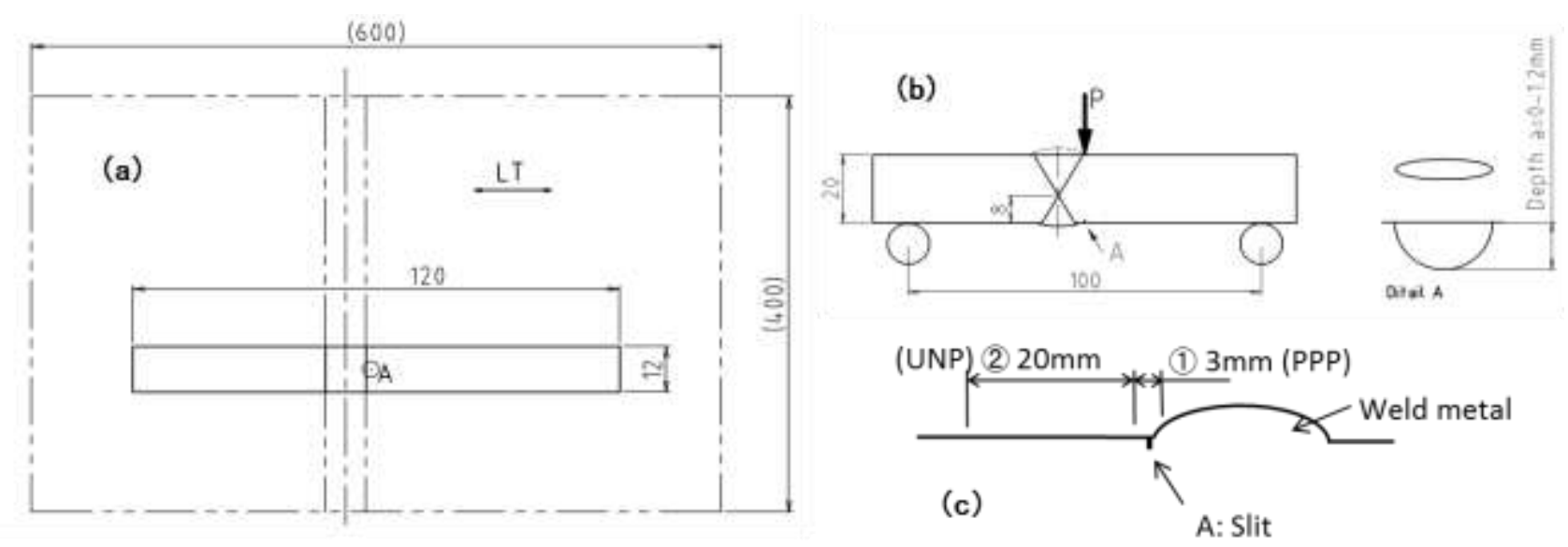

Fig. 1 Specimen for fatigue test, (a) As weld material, (b) test specimen, (c) detail of peening zone.

Table 1 Chemical composition and mechanical properties of SM490A. Chemical composition (wt\%)

\begin{tabular}{ccccc|cc}
$\mathrm{C}$ & $\mathrm{Si}$ & $\mathrm{Mn}$ & $\mathrm{P}$ & $\mathrm{S}$ & $0.2 \%$ proof & Tensile strength \\
\hline 0.15 & 0.32 & 1.11 & 0.018 & 0.005 & 371 & 511
\end{tabular}

Table 2 Peening conditions Weld toe

HAZ

$\begin{array}{lll}\text { (1)(PPP) } & \text { (2)(UNP) } \\ \text { Air pressure } \quad 0.5 \mathrm{MPa} & \text { Frequency } & 20 \mathrm{KHz} \\ \text { Radius of needle tip } \quad 1.5 \mathrm{~mm} & \text { Amplitude } 40 \mu \mathrm{m} \\ \text { Coverage }>100 \% & \text { Coverage }>100 \%\end{array}$




\section{1 疲労試験結果}

\section{3. 実験結果および考察}

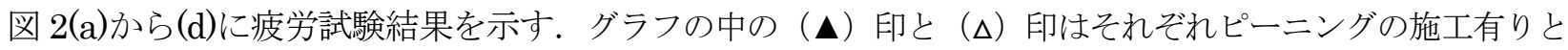
無しを表している. また矢印（）およびその（ ）内の数值は，未破断のまま試験を打ち切ったことと疲労限 度 $\sigma_{\mathrm{w}}$ をそれぞれ示している.ピーニングを施工した試験片では, 試験途中で破断した中にスリット以外の場所か ら破壞したものも現われ，それを図中で（*）印で表している.

図中のいずれの疲労試験結果もピーニングを施工することにより, 疲労限度が大きく向上している. 特に図 2(b) 一(d)のスリット材の場合で疲労限度向上が大きくなる傾向にあった. 疲労限度を向上させる要因は二つ考えられ る.ひとつはピーニング加工により溶接止端部近傍の危険な引張応力が改善され, 導入された圧縮残留応力がス リットからのき裂発生を阻止する働きがあること．もうひとつは溶接止端部がピーニングにより変形し，応力集 中を緩和したためだと考えられる．図 3 にピーニング施工した溶接止端部の写真を示す．写真上段と下段は，溶 接部を正面から撮影した写真と断面から撮影した写真をそれぞれ表している. 写真を見ると PPP 加工部は，元 の形状を破線で示したように加工後に大きくくぼんで変形していることがわかる. 変形後は止端部の曲率半径が 大きくなり，応力集中が緩和されたことが予想される，一方 UNP 加工部は表面に凹凸は確認されるものの大き な塑性変形は認められなかった。

次に図 $2(\mathrm{~b})$ と(c)を見ると，スリット深さ $a=0.4 \mathrm{~mm}$ および $1.2 \mathrm{~mm}$ の試験片は（）印で示したように，スリ ット以外から破壊に至っている. 図 4 に $a=1.2 \mathrm{~mm}$ のスリット材にピーニングを施工し, 試験途中で破断した試 験片の破面写真を示す．この写真を見ると，スリットから遠く離れた位置から破壊している.これはピーニング
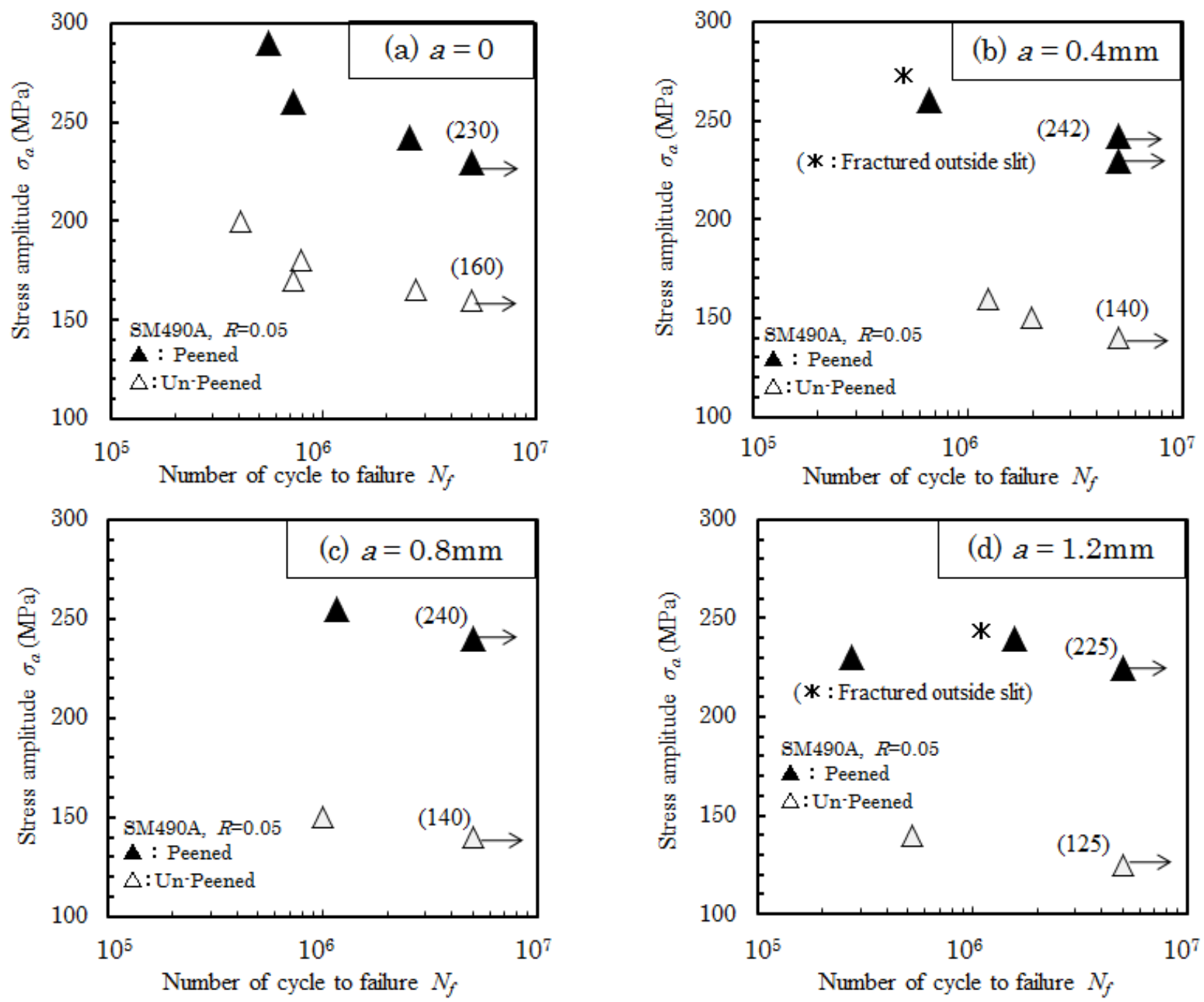

Fig. $2 S$ - $N$ curve for bending fatigue tests, (a) slit size $a=0$, (b) $a=0.4 \mathrm{~mm}$, (c) $a=0.8 \mathrm{~mm}$, (d) $a=1.2 \mathrm{~mm}$. 


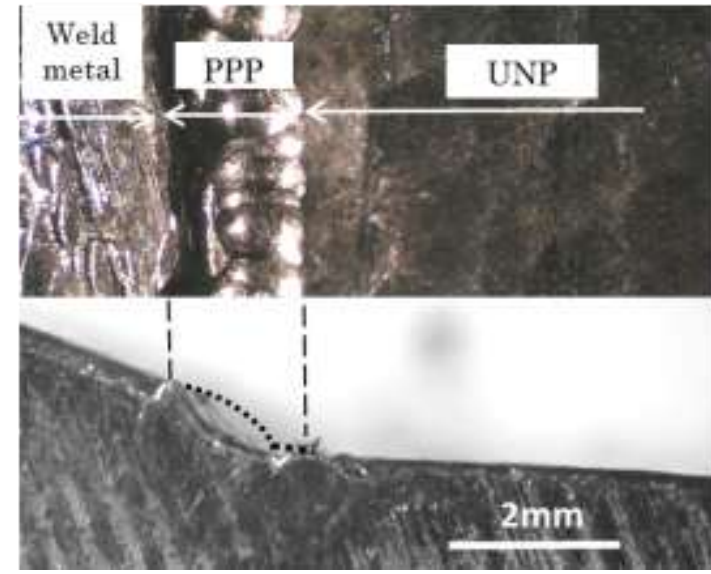

Fig. 3 Picture of weld toe with peening.

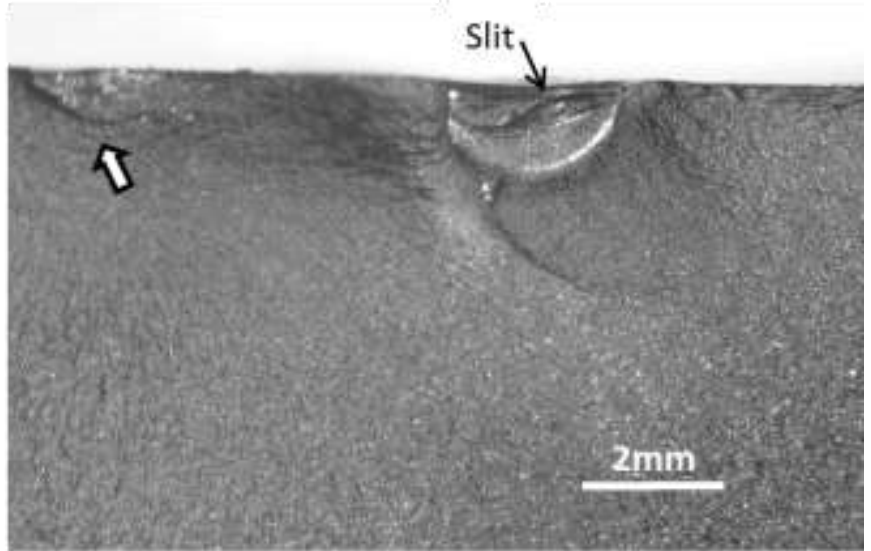

Fig. 4 Fracture surface of peened specimen which fractured outside slit.

加工による圧縮残留応力が相当に大きく，スリットが破壊に与える影響を十分に抑制できているためだと考えら れる。つまり疲労試験においてスリットの影響が消滅したことを示している.

\section{$3 \cdot 2$ き裂（スリット）の無害化}

き裂（欠陥を含む）寸法が金属材料の疲労限度に及ぼす影響において，疲労限度を低下させないき裂の限界寸 法があることが知られている。 つまりその寸法以下のき裂は事実上無害であるといえる.

これにならいスリットの無害化条件を以下の（I），（II)のように定義し，PPP および UNP 施工により無害化 可能なスリット寸法がどのように変化するのかを評価した.

（ I ）ピーニングを施工したスリット付き試験片の疲労限度が，スリット無しでピーニングを施工した試験片の 疲労限度に対して $95 \%$ 以内にまで向上すること.

（II）疲労試験においてピーニングを施工したスリット材がスリット部以外を起点として破断すること.

これらの条件のいずれかを満足するとき，そのスリットは無害化されたと定義する.

図 2 の疲労試験結果を, 横軸にスリット梁さ $a$, 縦軸に応力振幅 $\sigma a$ で整理し, 図 5 に示す.いずれも白抜き $(\triangle$,

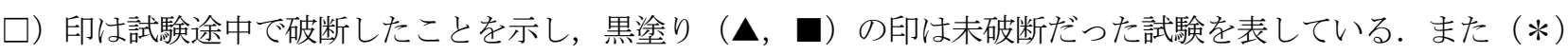
印はスリット部以外の場所から破断したことを示している. 図 5 を見ると，ピーニングを施工していない試験片 の疲労限度 $(\boldsymbol{a})$ はスリット深さ $a$ とともに徐々に低下している. 一方，ピーニングを施工した試験片の疲労限 度（山） はスリット深さ $a=0 \mathrm{~mm}$ から $1.2 \mathrm{~mm}$ までほとんどその值が低下していない. よってピーニングを施工 した試験片は, 条件 (I)を満足している. またの $a=0.4 \mathrm{~mm}$ と $1.2 \mathrm{~mm}$ のスリットを有する試験片にピーニングを

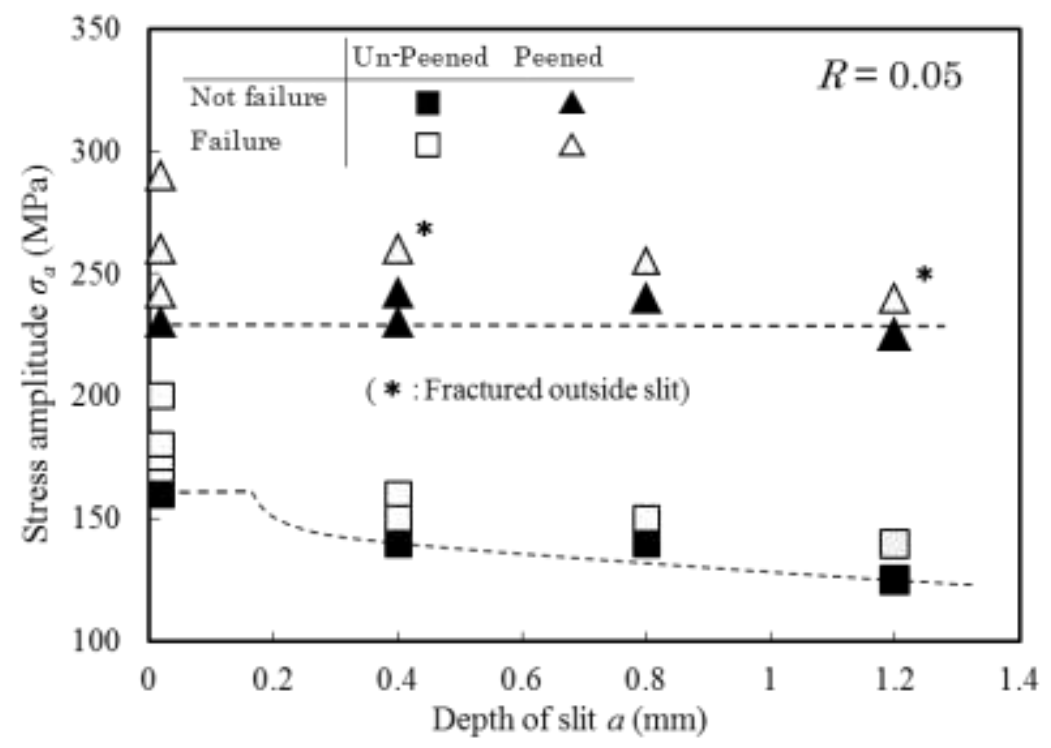

Fig. 5 Relationship between slit depth a and stress amplitude $\sigma_{\mathrm{a}}$. 
施工寸ると，前述のようにスリット外から疲労破壊していたので，条件(II)も同時に満足しているといえる.

以上のことから，溶接止端部近傍に PPP と UNP ピーニングを施工することにより，材料表面に存在する $a=1.2 \mathrm{~mm}$ のスリットを無害化できると結論された.これはショットピーニングにより高強度鋼に存在するスリ ットの無害化可能寸法が深さ $a=0.2 \mathrm{~mm}$ であること ${ }^{3,4)}$ ) と比較すると，極めて大きな寸法であるといえる.

\section{4. 結 論}

溶接構造用圧延鋼の溶接止端部に人工き裂(スリット)を導入し，ピーニング加工を施した試験片の疲労試験を 行ったところ次の結論が得られた.

（1）スリットの無い試験片もスリットを導入した試験片もピーニングを施工寸ることにより，疲労限度が大き く向上した．特にスリットを導入した試験片はピーニングを施工寸ることによる疲労限度の向上率が大きく， ス リットのない試験片と同等の疲労限度を示した.

（2）疲労試験で破断した試験はスリット外から破壊を起こし，ピーニング加工はスリットが疲労限度に与える 影響を消滅させることがわかった。

（3）ピーニング加工による疲労限度の向上は, 溶接止端部の応力改善に加えて塑性変形による応力集中の緩和 によると考えられる.

（4）ピーニングにより深さ $0.4-1.2 \mathrm{~mm}$ のき裂を疲労試験に対して無害化することができた.

\section{謝 辞}

試験片作成にはボイラー・圧力容器等研究助成金を使用し，またピーニング加工は東洋精鋼(株)に協力をいた だいた。ここに記して謝意を表す。

\section{文献}

(1) 野瀬哲郎, 島貫広志, “重齐継手の疲労寿命に及ぼす超音波ピーニングの影響に関する研究”, 日本機械学会論文集 A 編, Vol.74, No.737 (2008), pp.166-168.

(2) 本田尚, 佐々木哲也, 山際謙太, 山口篤志, “溶接継手の長寿命疲労特性評価”, 労衝安全衛生総合研究所特別研究 報告, JNIOSH-SRR-No. 40 (2010), pp.47-52.

(3) 高橋 宏治, 天野 利彦, 宮本 貴正, 安藤柱, 丹下彰, 岡田秀樹, 小野芳樹, “人工表面欠陥を有するばね鋼のショ ットピーニングによる疲労強度向上”, ば亦侖集, No.52 (2007), pp.9-13.

(4) 北條 恵司, 高橋 宏治, 安藤 柱, “応力集中部にき裂を有するば齐鋼のショットピーニングによる疲労限度向上お よびき裂の無害化”，ショットピーニング技術，Vol.24, No.1 (2011),pp.2-10.

(5) 高橋宏治, 佐野勇人, 北條恵司, 橋倉靖明, 水上博嗣, 安藤 柱, “過大予荷重による SCC, 疲労及び水素脆性き裂の 進展阻止とき裂の無害化”，保全学, Vol.10, No.1 (2011), pp20-27.

(6) Keiji Houjou, Kotoji Ando, Koji Takahashi, "Analytical investigation of effect of stress ratio on threshold stress intensity factor range improved by overload”, International Journal of Structural Integrity, Vol.3, No.1 (2012), pp.53-60. 